\title{
Evaluasi Kecernaan Energi dan Protein Dedak Padi Lokal pada Itik Mojosari Dara
}

(Evaluation of Metabolizable Energy and Protein of Rice Bran on Mojosari laying Ducks)

\author{
Asnawi, Dwi Kusuma Purnamasari, IKG. Wiryawan \\ Laboratorium Ilmu Produksi Unggas, Ilmu Nutrisi Non Ruminansia Fakultas Peternakan \\ Universitas Mataram Jl. Majapahit Mataram Lombok. Nusa Tenggara Barat. 83125 \\ Email : asnawipunia@gmail.com
}

Diterima : 15 Maret 2020/Disetujui : 18 Mei 2020

\begin{abstract}
ABSTRAK
Evaluasi energi metabolisme dedak padi lokal telah dilakukan pada itik petelur Mojosari. Tujuan penelitian ini adalah untuk menghitung nilai energi metabolisme yang terkandung dalam dedak padi lokal pada itik Mojosari yang sedang bertelur. Sepuluh ekor itik mojosari di alokasikan secara acak. Setiap ekor itik dipelihara dalam kandang individu (kandang metabolis). Dua type pakan yang diberikan yaitu pakan basal (30\% pakan komersial $+70 \%$ jagung) dan pakan percobaan (70\% pakan basal $+30 \%$ dedak padi lokal). Setiap type pakan terdapat lima ulangan dan setiap ulangan terdapat satu ekor itik. Energi metabilisme ditentukan berdasarkan metode Farrel (1978). Hasil penelitian diperoleh bahwa Gross Energi dan Appearent Energy Metabolis (AME) dedak padi lokal diperoleh sebesar 3317,00 $\pm 17,30$ $\mathrm{kkal} / \mathrm{kg}$ and $2461,44 \pm 27,76 \mathrm{kkal} / \mathrm{kg}$. Persentase AME terhadap Gross energy dedak lokal sebesar $74.21 \%$. Metabolizable protein of local rice bran were 55,71 $\pm 9,30 \%$ dari jumlah energi yang dikonsumsi. Dari hasil perhitungan apparent metabolic energy (AME) dan kecernaan protein, dedak padi lokal dapat digunakan sebagai pakan itik khusunya itik Mojosari.
\end{abstract}

Kata kunci: Dedak padi lokal, itik petelur energi metabolisme

\begin{abstract}
Evaluation of metabolizable energy of local rice bran have been conducted on Mojosari laying duck. The purpose of study was to calculate the energy values of local rice bran. Ten Mojosari laying ducks were randomly allocated of two types of feeds. Each laying duck was reared in individual cage (metabolic cage). Two types of feeds were basal diet (30\% commercial feed: $70 \%$ corn), and 70\% basal diet and 30\% local rice bran. There are five duck as replication in each types of feed. Metabolic energy (ME) was determined according to Farrel (1978) with any modification. The results indicated that the gross energy and apparent metabolically energy (AME) of rice bran were approximately $3317,00 \pm 17,30 \mathrm{kkal} / \mathrm{kg}$ and $2461,44 \pm 27,76 \mathrm{kkal} / \mathrm{kg}$. Presentation of AME to Gross energy of local rice bran were $74.21 \%$. Metabolizable protein of local rice bran were $55,71 \pm 9,30 \%$ from crude protein intake. It is concluded that according to apparent metabolically energy (AME) and digestible protein, local rice bran is appropriate as supplement feed of laying duct particularly Mojosari laying ducks.
\end{abstract}

Keywords: Local rice bran, laying duck, metabolizable energy 


\section{PENDAHULUAN}

Sistim pemeliharaan ternak itik di pulau Lombok pada umumnya adalah sistem terkurung dan tergabung dalam kelompok-kelompok ternak. Dalam sistim ini peternak dituntut untuk selalu menyediakan pakan yang sesuai dengan kebutuhan ternak itik. Salah satu pakan dasar yang biasa digunakan oleh peternak itik adalah dedak padi, karena bahan ini disamping harganya relatif murah dan juga mudah untuk didapatkan serta tersedia sepanjang tahun.

Penggunaan dedak padi sebagai campuran pakan itik di Indonesia khususnya di Pulau Lombok sudah umum dilakukan, dan itik lokal Indonesia sudah mampu beradaptasi dengan pakan berserat tinggi. Itik merupakan unggas yang paling tahan terhadap pakan berserat kasar tinggi, hal ini disebabkan seca itik berkembang lebih baik dibandingkan ayam. Di dalam seka itik terdapat mikroba yang mampu mencerna serat kasar menjadi asam lemak volatile yang digunakan untuk mensuplai kebutuhan energi (Yuanta, 2011). Iskandar $d k k$. (2001) melaporkan bahwa ternak itik mempunyai kemampuan beradaptasi secara biologis terhadap pakan berkadar dedak tinggi.

Dedak padi merupakan hasil sampingan dari penggilingan padi, jumlahnya sekitar $10 \%$ dari total berat padi. Pemanfaatan dedak sebagai pakan ternak sudah umum dilakukan. Kandungan zat makanan dedak padi sangat bervariasi tergantung dari jenis padi dan jenis mesin giling. Dedak padi mengandung karbohidrat yang tinggi sehingga dapat digunakan sebagai sumber energi bagi ternak. Penggunaan dedak padi sampai $75 \%$ dalam pakan itik petelur tidak mengganggu produksi telur, asalkan kandungan nutrisi yang lain cukup. Iskandar dkk. (2001) melaporkan itik Mojosari muda yang diberdedak padi lokal dedak $80 \%$ dan dedak padi lokal rucah $20 \%$ memiliki pertumbuhan yang lebih tinggi dibandingkan dengan pemberian pakan komersial ayam pedaging $80 \%$ dan dedak $20 \%$ dedak. Setioko (1997) melaporkan bahwa isi tembolok itik dewasa yang digembalakan sebahagian besar (76\%) terdiri dari komponen gabah.

Berbeda dengan penggunaan dedak pada ayam, belum mampu meningkatkan penampilan ayam walaupun dilakukan dengan berbagai macam pengolahan. Pemberian dedak yang dimasak dan di oven tidak berbeda nyata dengan diberi dedak padi lokal mentah dan di pellet, demikian juga walaupun ditambah anti oksidan sampai 250 ppm tidak memberikan pengaruh terhadap penampilan ayam broiler (Mujahid et al., 2010). Pemberian 400g/kg dedak dalam pakan menurunkan penampilan ayam (Farrell and Martin, 1998, Dadang, 2006).

Penyusunan pakan itik di Indonesia pada umumnya berpatokan pada kandungan bahan pakan yang dikeluarkan oleh peneliti-peneliti luar negeri, sementara itu komposisi bahan pakan local berbeda dengan yang ada di luar negeri. Informasi tentang kecernaan energi dan protein dedak lokal belum diketahui dan belum dilakukan pengujian secara biologis. Informasi tersebut sangat 
penting dalam penyusunan ransum unggas terutama ternak itik. Penelitian ini bertujuan untuk mengetahui energi metabolis (AME dan TME) dan kecernaan protein dedak local pada itik Mojosari dara.

\section{MATERI AND METODE}

Percobaan ini menggunakan ternak itik Mojosari dara sebanyak 10 ekor berumur 4 bulan dengan kisaran bobot badan yang homogen. Semua itik diperlakukan setelah mengalami adaptasi lingkungan selama satu bulan, sehingga pada waktu penelitian itik sudah berumur lima bulan. Semua itik ditempatkan di kandang battery indiividu, kandang berukuran panjang x lebar x linggi: 55 x $35 \times 60 \mathrm{~cm}$, ditempatkan di ruang tertutup dengan ventilasi yang cukup. Air minum itik diberikan secara ad libitum. Bahan pakan yang ditentukan kandungan energinya adalah dedak padi (kualitas sedang).

Alat-alat yang digunakakan untuk pelaksanaan determinasi EM terdiri dan timbangan merk "Ohaus" untuk menimbang itik, timbangan elektrik untuk sampel bahan dan feses, kantong plastik, wadah plastik, tempat penampung kotoran yang terbuat fibre glass, oven dan alat penggilingan sampel. Metode yang digunakan dalam penelitian ini adalah percobaan di lapang dengan menggunakan Rancangan Acak Lengkap (RAL). Jumlah perlakuan ditetapkan 2 jenis yaitu $\mathrm{P} 0=$ ransum basan dan $\mathrm{P} 1$ = pakan uji $(30 \%$ dedak dan $70 \%$ pakan basal), masingmasing perlakuan diulang 5 kali, setiap ulangan terdiri dari satu ekor itik yang ditempatkan dalam satu kandang metabolis.

Sebelum dilakukan perlakuan, itik dipelihara dikandang metabolis dan diadaptasikan selama 1 minggu. Koleksi ekskreta dilakukan selama tiga hari. Ekskreta yang terkumpul dikeringkan dibawah sinar matahari selama satu hari atau sampai beratnya konstan. Selanjutnya ekskreta dimasukkan ke oven $60^{\circ} \mathrm{C}$ selama 24 jam dan ditimbang, kemudian ekskreta hasil penampungan selama tiga hari tersebut digiling dan selanjutnya dianalisis kandungan bahan kering (BK), gross energy (GE), dan protein kasar (PK). Gross energy dianalisis dengan adiabatik Bomb Calorimeter. Sedangkan kandungan protein kasar dianalisis dengan metode Kjeldahl. Susunan bahan pakan basal disajikan pada table 1 . 
Tabel 1. Susunan dan Kandungan Zat Pakan Basal Itik

\begin{tabular}{lr}
\hline Bahan Pakan & Jumlah (\%) \\
\hline Jagung kuning & 65 \\
Konsentrat itik & 34 \\
Premix & 1 \\
\hline Jumlah & 100 \\
\hline Kandungan zat pakan hasil perhitungan & 3097 \\
\hline Energi metabolis (Kkal/kg) & 17.345 \\
Protein kasar (\%) & 3.83 \\
Serat kasar (\%) & 4.345 \\
Lemak kasar (\%) & 3.7465 \\
Ca (\%) & 0.522 \\
P (\%) & 0.44 \\
Methionin (\%) & 1.05 \\
Lysin (\%)
\end{tabular}

Variabel yang diamati meliputi :

Kecernaan protein, ditentukan dengan menggunakan persamaan menurut Sholeh $d k k$. (2012) yaitu:

Kecernaan protein $(\%)=\frac{A-B}{A} \times 100$

Keterangan:

$\begin{array}{ll}\mathrm{A} & =[\text { konsumsi pakan }(\mathrm{g}) \mathrm{x} \% \mathrm{BK} \text { pakan }] \\ & \mathrm{x} \% \text { PK pakan } \\ \mathrm{B} & =\text { berat kering ekskreta }(\mathrm{g}) \mathrm{x} \% \text { protein } \\ & \text { ekskreta } \\ \text { PK } & =\text { protein kasar } \\ \text { BK } & =\text { bahan kering }\end{array}$

Energi metabolis, ditentukan menggunakan persamaan menurut Farrel (1978) yaitu:

$\operatorname{ME}(\mathrm{Kkal} / \mathrm{Kg})=\frac{(A x B)-(C \times D)}{A} \times \frac{100}{B K}$

Keterangan:

$\mathrm{A}=$ Konsumsi pakan

$\mathrm{B}=$ Energi bruto dari pakan

$\mathrm{C}=$ Jumlah ekskreta

$\mathrm{D}=$ Energi bruto dari ekskreta

$\mathrm{BK}=$ Kandungan bahan kering

Energi metabolis terkoreksi nitrogen (AMEn) ditentukan dengan menggunakan persamaan menurut Farrel (1978) yaitu:
AMEn $(\mathrm{Kkal} / \mathrm{Kg})=\frac{(A \times B)-(C \times D)}{A} \times \frac{100}{B K} 8,73 \times$ retensi $\mathrm{N}$

Keterangan:

A $=$ Konsumsi pakan

$\mathrm{B}=$ Energi bruto dari pakan

$\mathrm{C}=$ Jumlah ekskreta

D $\quad=$ Energi bruto dari ekskreta

BK = Kandungan bahan kering

Retensi $\mathrm{N}=\mathrm{N}$ dikonsumsi $-\mathrm{N}$ ekskreta

Analisis Statistik. Data ditabulasi dan dihitung menggunaakan program MS Excel, kemudian data kecernaan protein, energi metabolis, disajikan secara diskriptif.

\section{HASIL DAN PEMBAHASAN}

Hasil evaluasi Aperent Metabolis Energi (AME) dedak padi lokal diperoleh sebesar 2461,44 $\pm 27,26 \mathrm{kkal} / \mathrm{kg}$ (table 2). Hasil tersebut lebih tinggi dibandingkan dengan hasil penelitian Haryono dan Ujianto (2000) sebesar 2531,25 $\pm 16,70$ $\mathrm{kkal} / \mathrm{kg}$, lebih rendah dibandingkakan dengan NRC (1994) sebesar $2980 \mathrm{kkal} / \mathrm{kg}$, Hoai et al (2011) sebesar $12,87 \mathrm{Mj} / \mathrm{kg}$ untuk itik masa pertumbuhan, Nadem et al (2005) sebesar $3016 \mathrm{kkal} / \mathrm{kg}$ pada ayam petelur leghorn. Hasil evaluasi True 
Metabolism Energi (TME) dedak padi local diperoleh sebesar 2473,76 $\pm 27,71$ $\mathrm{kkal} / \mathrm{kg}$. hasil tersebut lebih rendah dibandingkan dengan TME yang dilaporkan Nadem et al (2005) yang mendapatkan sebesar $3436 \pm 25,74$ $\mathrm{kkal} / \mathrm{kg}$. Perbedaan hasil tersebut disebabkan kualitas padi yang membentuk dedak (Akbarillah, dkk., 2007). Dedak lokal yang diuji dalam penelitian ini adalah dedak local kelas II yang biasa digunakan oleh peternak itik, dedak local kelas II biasanya memiliki serat kasar lebih tinggi di bandingkan dengan kelas I maupun super. Serat kasar yang tinggi akan menurunkan energi metabolis pakan, karena terjadinya penurunan kecernaan bahan, sehingga terjadinya penurunan penyerapan zat zat makanan. Tingkat energi metabolis berhubungan erat dengan kecernaan dan penyerapan zat zat makanan. Hal ini sejalan dengan yang dilaporkan oleh McDonald et al. (1994), bahwa energi metabolis ditentukan oleh kandungan dan keseimbangan nutrisi bahan dan serat kasar merupakan faktor utama yang menentukan nilai energi metabolism. Hasil penelitian evaluasi kecernaan protein ikan dedak padi local disajikan pada Tabel 3.

Tabel 2. Perkiraan energi metabolis dan kecernaan protein dedak padi lokal sebagai pakan itik Mojosari.

\begin{tabular}{lllll}
\hline \multirow{2}{*}{ Parameter } & \multicolumn{4}{c}{ Bahan pakan uji } \\
\cline { 2 - 5 } & Dedak & Sd & Basal & Sd \\
\hline Konsumsi pakan $(\mathrm{g})$ & 81,18 & 4,52 & 78,08 & 3,99 \\
Konsumsi energi (Kkal/kg) & 279735,73 & 265,56 & 273365,89 & 236,01 \\
Jumlah Exkreta (g) & 16,70 & 3,21 & 12,73 & 1,73 \\
Jumlah energi exkreta (Kkal/g) & 46694,14 & 169,22 & 31244,34 & 58,71 \\
AME (Kkal/kg) & 2461,44 & 27,76 & 3401,18 & 17,26 \\
TME (Kkal/kg) & 2473,76 & 27,71 & 3413,04 & 17,26 \\
GE (Kkal/kg) & 3317,00 & & 3501,10 & \\
\% ME terhadap GE & 74,21 & & 97,15 & \\
\hline
\end{tabular}

Tabel 3. Kecernaan protein sapu-sapu, dedak dan pakan basal

\begin{tabular}{lllll}
\hline \multirow{2}{*}{ Parameter } & \multicolumn{3}{c}{ Bahan pakan uji } \\
\cline { 2 - 5 } & Dedak & Sd & Basal & Sd \\
\hline Konsumsi protein $(\mathrm{g})$ & 10,00 & 2,52 & 11,64 & 2,37 \\
Protein ekskreta $(\mathrm{g})$ & 3,89 & 2,78 & 5,02 & 0,85 \\
Kecernaan protein $(\%)$ & 62,78 & 21,21 & 55,71 & 9,30 \\
\hline
\end{tabular}

\section{KESIMPULAN}

Dari hasil penelitian dapat disimpulkan bahwa dedak padi lokal berpotensi digunakan sebagai pakan itik Mojosari.

\section{DAFTAR PUSTAKA}

Akbarillah T., Hidayat dan T. Khoiriyah., 2007. Kualitas Dedak dari Berbagai Varietas Padi di bengkulu Utara ,, Jurnal Sain Peternakan Indonesia Vol. 2, No 1, : 36-41 
Dadang R.A. 2006. Effect of rice bran and phytase supplementation on egg laying performance and egg quality of laying hens. Thesis Degree Master of Science. University Putra Malaysia.

Farrel, D.J. 1978. Rapid determinant of metabolizable energy of foods using cokrerels. British Poultry Sci. 19 (3): 303-308.

Farrel, D, J. and E.A. Martin. 1998 . Strategies ti improve the nutritive value of rice bran in poultry diet. I. The additional of food enzymes to target the non-strach polysacaride fraction in diets of chickens and ducks gave no response. British Poultry Science, 39: 349-554.

Farrel, D, J. and E.A. Martin. 1998 ${ }^{\mathrm{b}}$. Strategies ti improve the nutritive value of rice bran in poultry diet. III. The additional of inorganic phosphorus and a phytase to duck diet. British Poultry Science, 39: 601-611.

Hoai H.T., L.V. Kinh, T. Q.Viet, P.V. Sy, N.V. Hop, D.K. Oanh, N.T. Yen. 2011. Determination of the metabolizable energy content of common feedstuffs in meat-type growing ducks. Anim. Feed Sci. Technol. (2011), doi: 10.1016/j.anifeedsci.2011.07.

Iskandar, S., V.S. Nugroho, D. M. Suci dan A.R. Setioko. 2001. Adaptasi biologis itik jantan muda lakal terhadap pakan berkadar dedak padi tinggi. Lokakarya Nasional Unggas Air. Balai Penelitian ternak Ciawi Bogor. 118-127

Maryono dan A. Ujianto. 2000. Penentuan energi metabolis (EM) bahan pakan ayam di kandang percobaan unggas Ciawi Bogor. Temu Teknis Non Peneliti BPT Ciaawi Bogor.

Mc Donald, P., R.A. Edwards and J. F. D. Greennalgh (1988).

Animal
Nutrition. 2nd Ed. The English Language Book Society and Longman, London.

Mujahid A., I. Ul Haq, M. Asif and A. Husain Gilani. 2004. Effect of different levels of rise bran processed by various techniques on performance of broiler chicks. British Poultry Science. 45 : 395399.

Nadeem M. A, A.H.Gilani, A.G.Khan and Mahr-Un-Nisa. 2005. True Metabolizable Energy Values of Poultry Feedstuffs in Pakistan. Iternational Journal of Agriculture and Biology 1560-8530/2005/076-990-994 http://www.ijab.org.

NRC. 1994. Nutrient Requirement of Poultry. $9^{\text {th }}$ Revised Edition. National Research Council, National Academy, Washington.

Sholeh, T., W. Sarengat dan U. Atmomarsono. 2012. Pengaruh erbedaan lama periode pemberian pakan dan level protein terhadap laju pakan, konsumsi protein dan kecernaan protein ayam pelung umur 1 minggu sampai 11 minggu. Animal Agricultural Journal. 1 (1): 133-142.

Setioko, A.R. 1990. Pola pengembangan peternakan itik di Indonesia. Prosiding Temu Tugas Sub-Sektor Peternakan No.5: Pengembangan usaha ternak itik di Jawa Tengah, Sub Balai Penelitian Ternak Klepu.

Yuanta, T., Zuprizal, Endang S. R., dan R. Sutrisno. 2011. Kontribusi pencernaan fermentatif itik yang menggunakan limbah industry pertanian sebagai sumber serat kasar dalam pakan. http://www.digilib.ugm. 